\title{
PUSAT OLAHRAGA KEMBANGAN SELATAN
}

\author{
Adi Subrata ${ }^{1)}$, Tony Winata ${ }^{21}$ \\ 1)Program Studi S1 Arsitektur, Fakultas Teknik, Universitas Tarumanagara, adii_tan98@yahoo.com \\ ${ }^{2)}$ Program Studi S1 Arsitektur, Fakultas Teknik, Universitas Tarumanagara, tonywinata@ft.untar.ac.id
}

\begin{abstract}
Abstrak
Mobilitas yang tinggi dalam suatu kawasan serta perkembangan teknologi yang terus terjadi secara pesat dinilai mempengaruhi kondisi stress pada milenial. Untuk menghilangkan stress tersebut dapat dilakukan berbagai macam kegiatan salah satunya adalah olahraga. Selain sebagai penjaga kebugaran tubuh, olahraga juga dapat digunakan sebagai penghilang stress. Olahraga yang diminati kaum millenial sekarang salah satunya adalah olahraga yang bersifat hiburan. Karakter milenial yang cenderung individual tentunya berdampak terhadap jenis olahraga yang dimainkan. Proyek Pusat Olahraga Kembangan Selatan didesain dengan kesesuaian kebutuhan millenial terhadap jenis olahraga, pemfokusan terhadap program olahraga yang dipilih dapat membantu menghilangkan stress pada millenial, serta dapat sebagai hiburan dan tidak memerlukan bantuan orang lain dalam melakukan aktivitas. Jenis olahraga baru dalam bangunan diharapkan dapat memberikan wajah baru dari sebuah fasilitas olahraga umum di masyarakat.
\end{abstract}

Kata kunci: Hiburan; Individual; Millenial; Olahraga; Stress

\begin{abstract}
Higher mobility in an area with technological developments that continue to increase in the future, to eliminate stress is carried out by a variety of activities, one of which is sports. Apart from maintaining fitness, exercise can also be used as a stress reliever. Sports that are of interest to millennials are now one of the liberating sports. Millennial characters taken by individuals that have an impact on the type of sport being played. Buildings are designed to suit millennial needs for the type of exercise, focusing on selected exercise programs can help relieve stress in millennials, as well as helping and helping others in carrying out activities. Apart from that a new type of sport in the building that can provide a new face from the public Sports Facility in the community. Space is designed from contextual results and site analysis produces a form of space that effectively increases chemicals with the region.
\end{abstract}

Keywords: Entertainment; Individual; Millenial; Sport; Stress

\section{PENDAHULUAN}

Millenial merupakan generasi Y, yang terdiri dari masyarakat tahun 1989-2000. Generasi ini terbilang unik dan menarik dikarenakan generasi ini sebagai perantara penting antara generasi $X$, Baby Boomer dengan generasi $Z$ yang penuh dengan teknologi. Generasi milenial memiliki berbagai macam karakter seperti penyuka internet, multitask, kreatif, cepat bosan, serta penyuka hal baru. Dari pemunculan karakter tersebut berdampak terhadap perkembangan kota dan fasilitasnya yang dihuni oleh generasi milenial.

Pemikiran yang kreatif, cepat bosan, serta penyuka hal baru merupakan karakter yang berbeda dari generasi lainnya ( $X$ dan Baby Boomer) sehingga hal ini membuat kemungkinan ketidakcocokan antara fasilitas yang telah ada dengan penggunanya sekarang ini. Ketidakcocokan tersebut berdampak bagi munculnya ketidaknyamanan ataupun merasa tidak sesuai dengan karakter yang berdampak stress yang mengakibatkan fasilitas yang disediakan tidak dipakai oleh milenial. 
Hal ini terbukti dari tabel yang diperoleh dari hasil survey Zipjet mengenai "The 2017 Global Least \& Most Stressfull Cities Ranking" yang menunjukkan Jakarta sebagai kota paling stress ke-18 di dunia (Gambar 1).

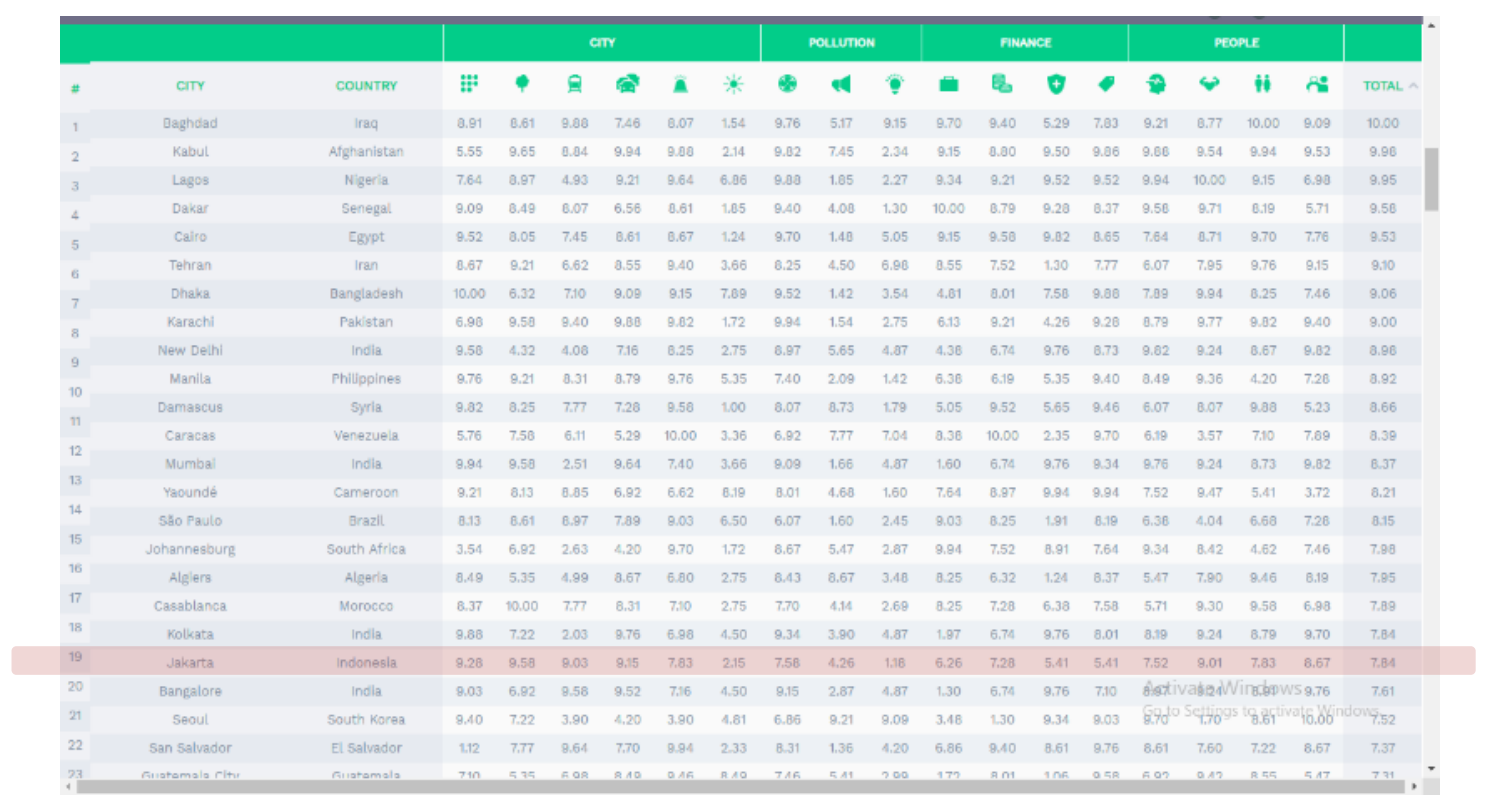

Gambar 1. 2017 Stressful Cities ranking

Sumber: Zipjet-UK

Dengan permasalahan stress tersebut, milenial melakukan berbagai aktivitas yang dapat membantu menghilangkan stress pada diri mereka. Seperti rekreasi dan berolahraga. Pemilihan proyek fasilitas olahraga merupakan jawaban atas masalah dari stress pada milenial, dengan menyediakan sebuah wadah penyegaran dan pemugaran fisik dan mental generasi milenial.

\section{KAJIAN LITERATUR}

\section{Generasi Milenial}

Istilah generasi milenial memang sedang akrab terdengar. Istilah tersebut berasal dari millennials yang diciptakan oleh dua pakar sejarah dan penulis Amerika, William Strauss dan Neil Howe dalam beberapa bukunya. Millennial generation atau generasi Y juga akrab disebut generation me atau echo boomers. Para pakar menggolongkannya berdasarkan tahun awal dan akhir. Penggolongan generasi Y terbentuk bagi mereka yang lahir pada 1980 - 1990, atau pada awal 2000, dan seterusnya. Generasi tersebut dicirikan dengan pemikiran kreatif, selalu menyukai hal baru, pecandu internet, multitask, tidak tertarik politik, cepat bosan, dan mementingkan diri sendiri.

\section{Olahraga}

Olahraga merupakan aktivitas yang sudah sangat umum didengar dan pernah kita lakukan. Menurut Jessica Dolland, olahraga merupakan media pereda stress yang terbaik yang pernah ada. Olahraga dapat mengalihkan pikiran manusia dari rasa khawatir dengan jalan meredakan berbagai ketegangan otot yang ada pada. Serta Menurut Dewan Olah Raga Eropa, pengertian olahraga adalah setiap aktivitas spontan, bebas, yang dilaksanakan dalam waktu luang. Sehingga dapat disimpulkan bahwa pada dasarnya olah raga berfungsi untuk menjaga, meningkatkan, menyeimbangkan kesehatan sistem jasmani dan rohani seseorang. 


\section{Olahraga pada Millenial}

Olahraga merupakan kegiatan yang diminati oleh seluruh kalangan di dunia, salah satunya adalah generasi milenial. Berdasarkan hasil survey dari Centre For Strategic and International Studies terhadap generasi milenial dan non milenial yang ada di Jakarta mengenai kegiatan yang dapat membantu menghilangkan stress pada diri mereka.

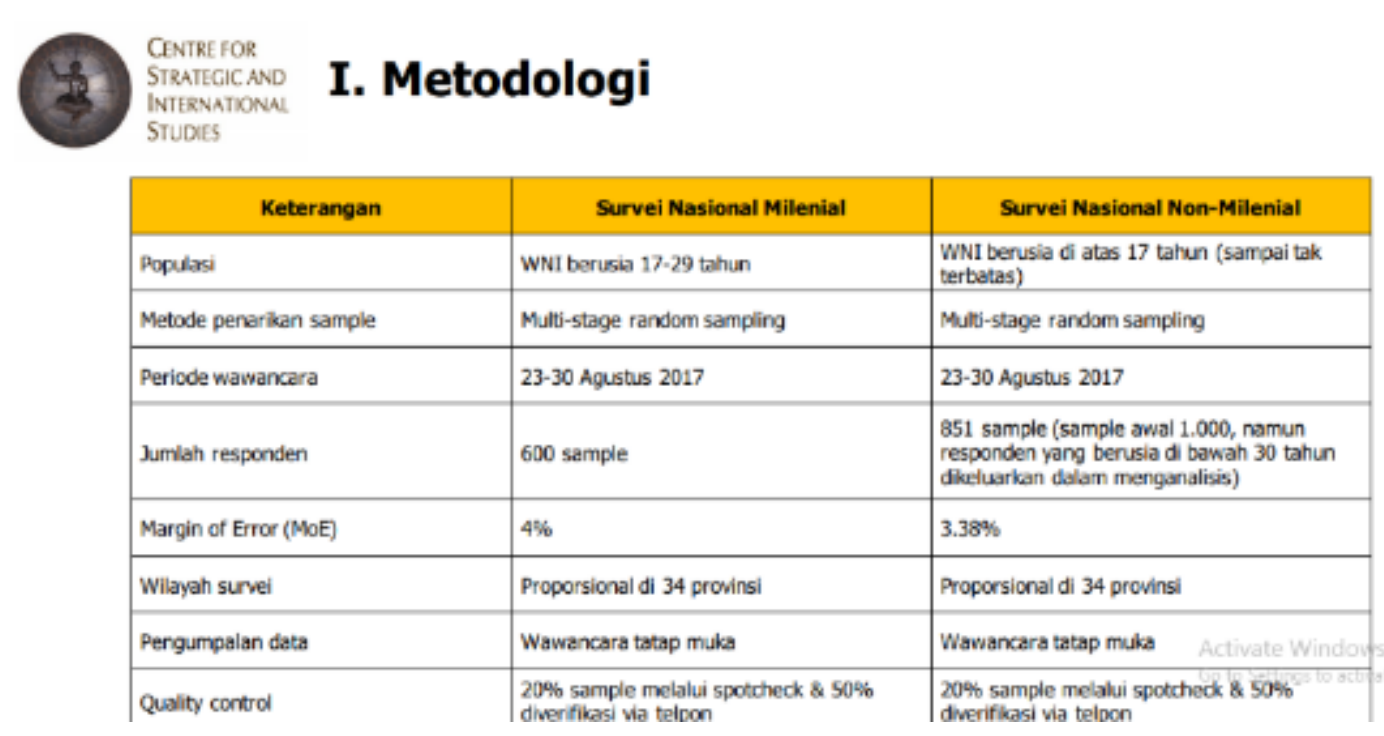

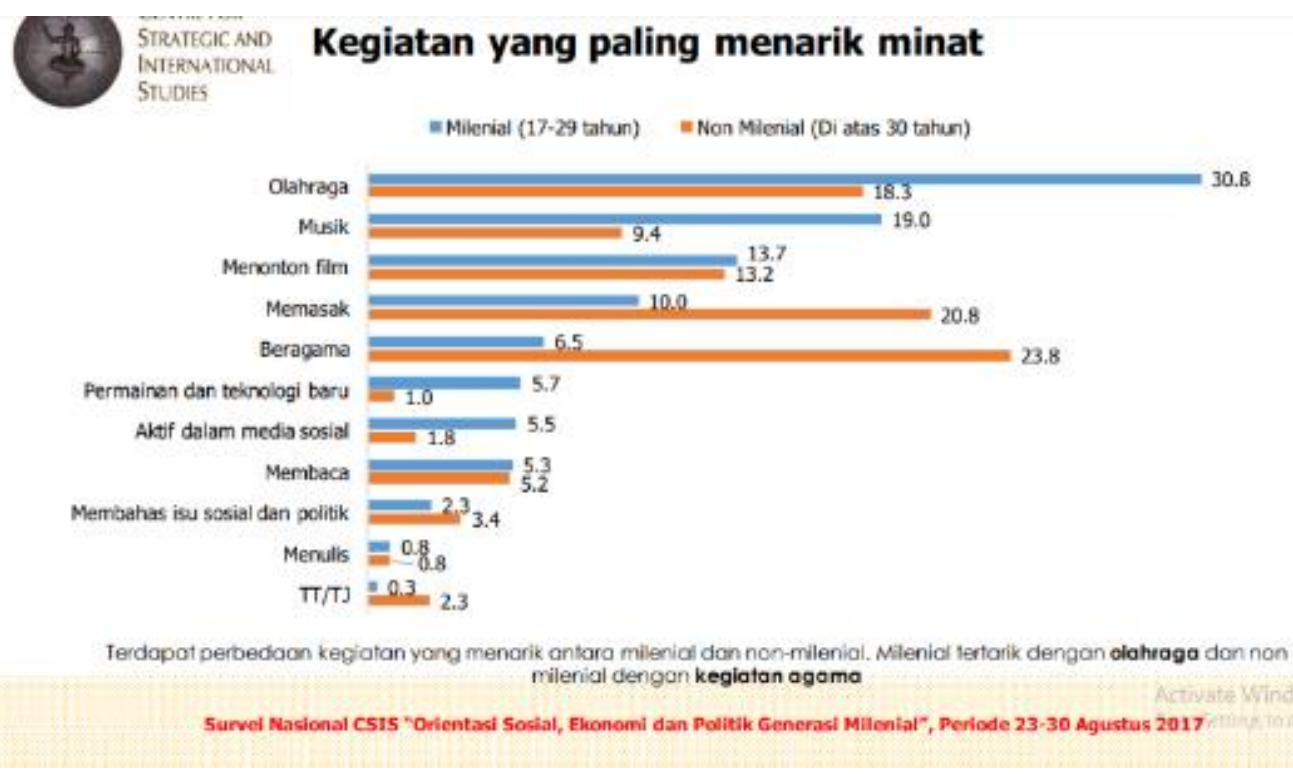

Gambar 2. Tabel Survey Terkait Generasi Milenial Sumber: Centre For Strategic And International Studies

Dari perolehan tabel analisa yang dilakukan oleh Centre For Strategic And International Studies menunjukkan beberapa aktivitas yang paling diminati oleh kaum milenial Indonesia. Salah satu aktivitas tersebut adalah berolahraga. Hal ini ditunjukkan dengan angka minat milenial terhadap kegiatan olahraga yang mencapai $30.8 \%$ dalam minat olahraga. Sedangkan aktivitas yang paling diminati oleh kaum lainnya (Generasi $X$ dan Baby Boomers) adalah beragama. 


\section{METODE}

\section{Pemilihan Tapak}

Pemilihan tapak dilakukan dengan melakukan analisis data terhadap jumlah milenial di setiap daerah sebagai penentuan awal. Setelah menentukan lokasi tapak dari isu yang didapat di kawasan, penulis melakukan analisis tapak untuk memperoleh data spesifik dari tapak.

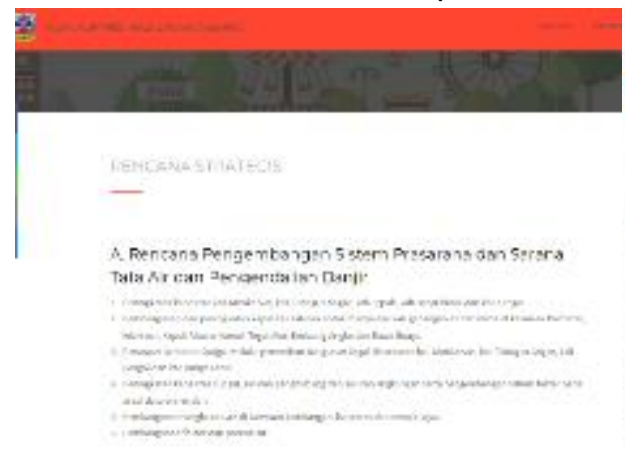

2018, Infrastruktur dan Ekonomi Jakarta Barat Semaldn Berkembang

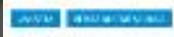

Gambar 3. Data dan Isu Kembangan Selatan - Jakarta Barat Sumber: Dokumentasi Pribadi, 2019
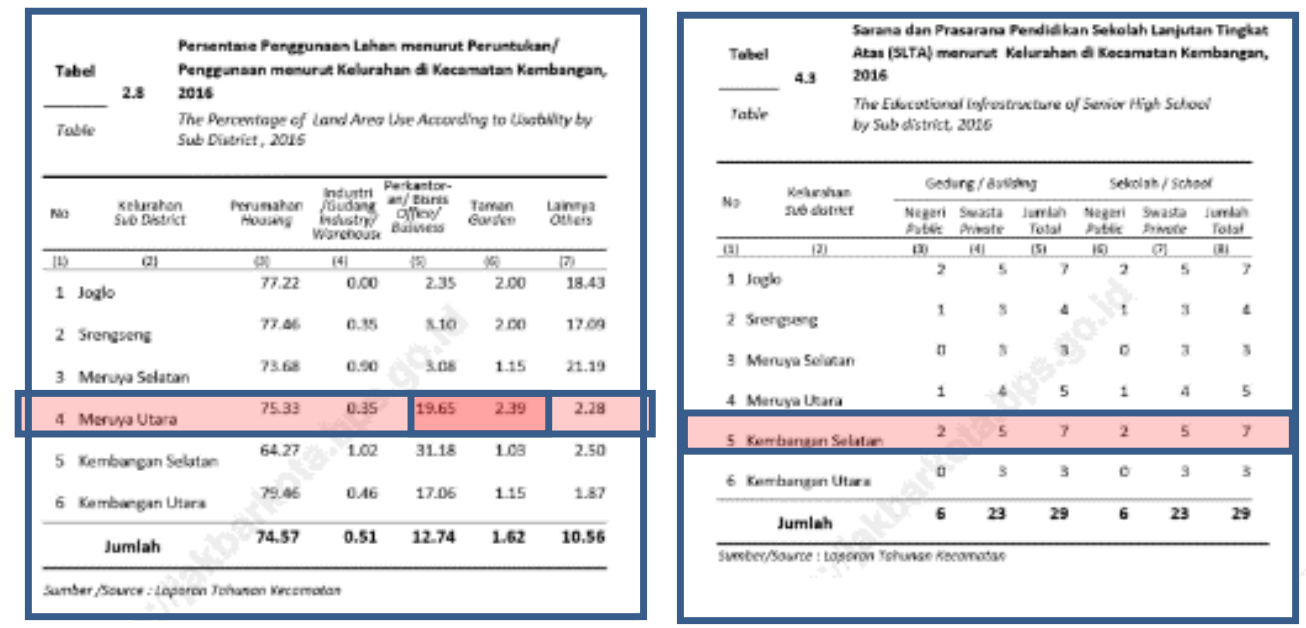

Gambar 4. Data dan Isu Kembangan Selatan - Jakarta Barat Sumber: Laporan Tahunan Kecamatan Kembangan

\begin{tabular}{|c|c|c|c|c|c|c|}
\hline \multirow{3}{*}{$\begin{array}{l}\text { Tabel } \\
\text { Table } \\
\text { No }\end{array}$} & \multirow{2}{*}{4.6} & \multirow{2}{*}{\multicolumn{5}{|c|}{$\begin{array}{l}\text { Kelurahan di Kecamatan Kembarngan } 2015 \\
\text { The Number of Sport Faethities bosed an Kind of Sports } \\
\text { and Sub District, } 2015\end{array}$}} \\
\hline & & & & & & \\
\hline & $\begin{array}{l}\text { Kelirnhan } \\
\text { Sab Ostrnct }\end{array}$ & \multirow{2}{*}{$\begin{array}{c}\text { Sepook } \\
\text { Bstlo } \\
\text { socest } \\
\text { (3) }\end{array}$} & \multirow{2}{*}{$\begin{array}{l}\text { Tenis } \\
\text { Temnis } \\
\text { [t] }\end{array}$} & $\begin{array}{l}\text { Bulu Tangets B } \\
\text { Botmintion }\end{array}$ & $\begin{array}{l}\text { Bols volley } \\
\text { valky }\end{array}$ & $\begin{array}{l}\text { Bola Basket } \\
\text { Bosiket }\end{array}$ \\
\hline (1) & (2) & & & (5) & (b) & (n) \\
\hline & toelo & 1 & & 4 & 3 & 1 \\
\hline & Srenesere & 1 & & 8 & 2 & 2 \\
\hline & Meruya Selatan & 0 & & 9 & 2 & 2 \\
\hline & Meruy Unara & 1 & & 10 & 5 & 3 \\
\hline 5 & Kembangan Selatan & 1 & & 6 & 4 & 2 \\
\hline & Kembangan Utaro & 1 & & 12 & 4 & 3 \\
\hline & Jumlah & 5 & 14 & 49 & 20 & 13 \\
\hline
\end{tabular}

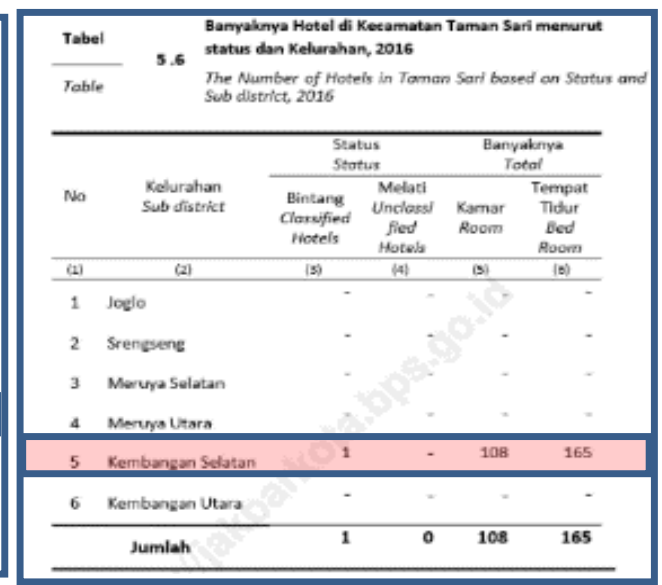

Gambar 5. Data dan Isu Kembangan Selatan - Jakarta Barat Sumber: Laporan Tahunan Kecamatan Kembangan 
Dari data yang diperoleh menunjukkan bahwa di Kembangan Selatan memiliki angka tertinggi untuk pemanfaatan lahan di kawasan sebagai area perkantoran dan paling sedikit untuk Taman Kota. Selain itu fasilitas olahraga di kawasan sudah terbilang cukup untuk menangani kawasan, sehingga program olahraga dari Kembangan Sport Center dapat fokus terhadap olahraga yang bersifat permainan/ hiburan saja. Selain itu, di daerah Kembangan Selatan juga terdapat hotel berbintang yang berstandar internasional dan dapat menunjang kawasan. Hal ini dikarenakan isu yang berada di kawasan Jakarta Barat bahwa akan dibangunkannya CBD (Central Business District) di daerah Jakarta Barat di daerah Puri sehingga akan berdampak terhadap daerah sekitarny salah satunya adalah Kembangan Selatan. Persiapan untuk kawasan CBD tersebut sudah dilakukan oleh kawasan Kembangan Selatan yang berada dekat di samping Puri Indah tempat CBD Jakarta Barat yang akan datang.

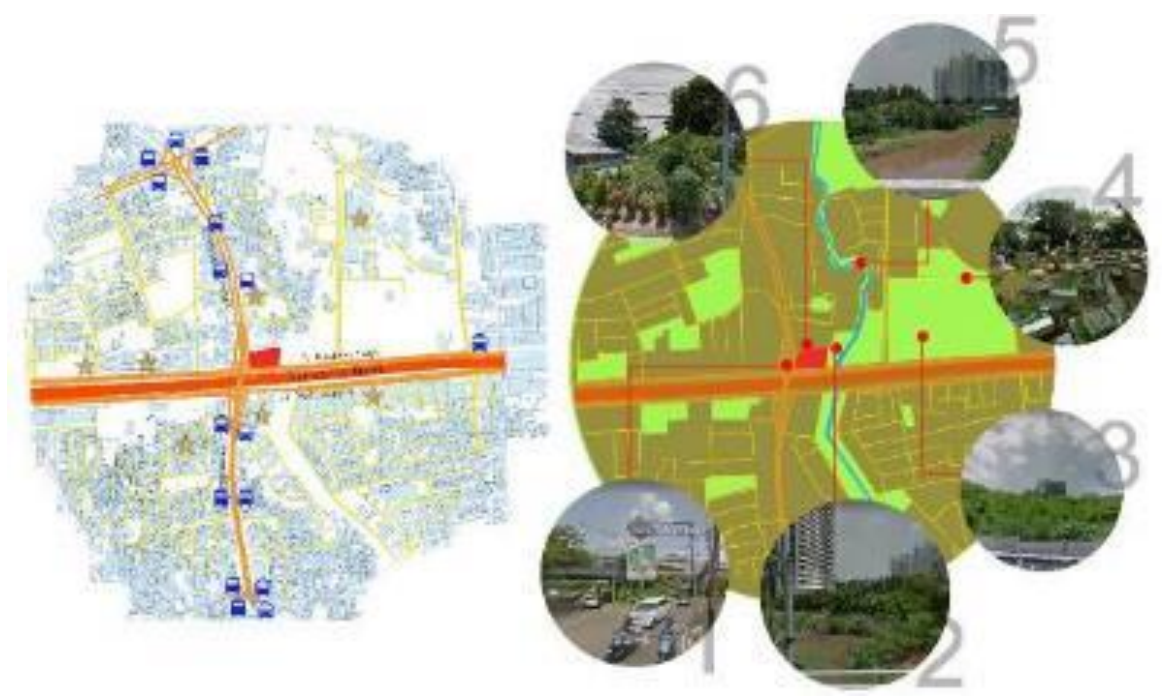

Gambar 6. Analisis Kawasan Kembangan Selatan - Jakarta Barat Sumber: Penulis, 2019
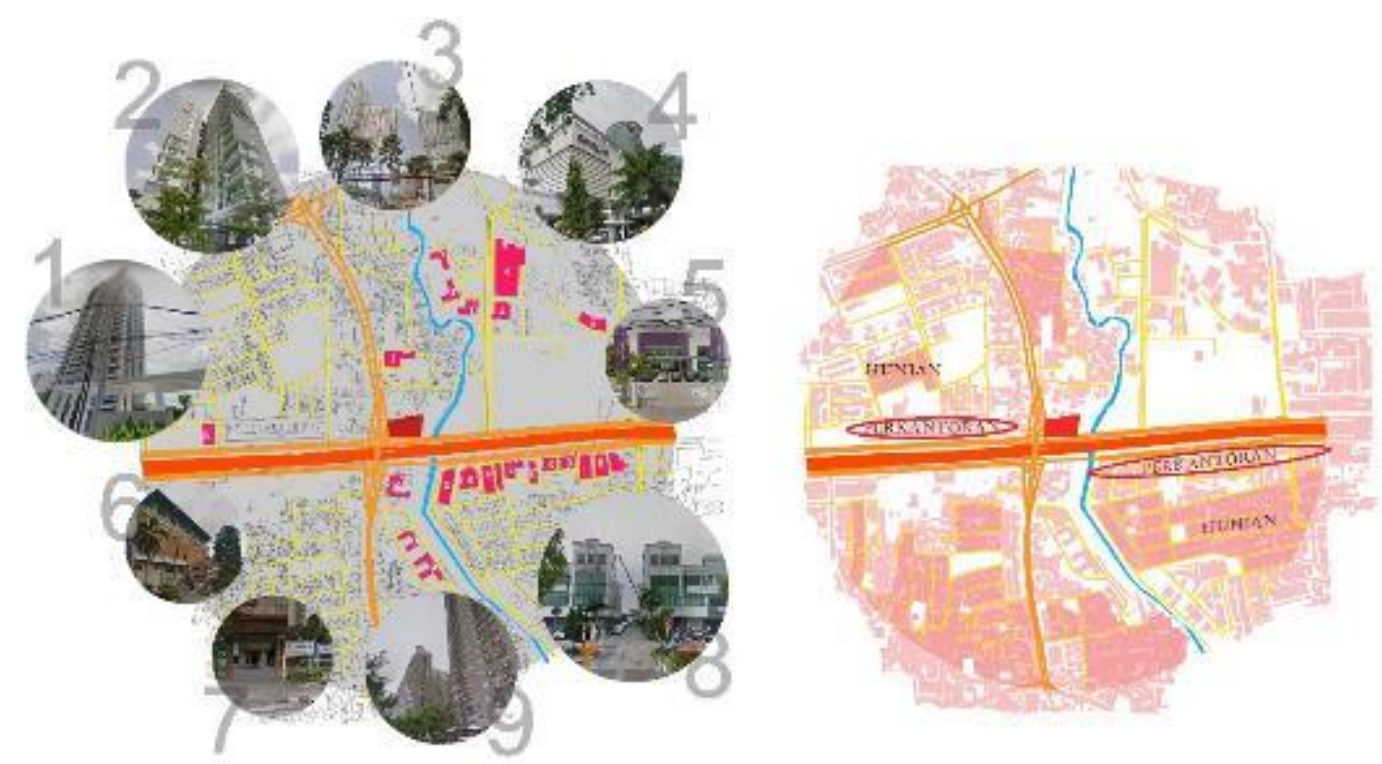

Gambar 7. Analisis Kawasan Kembangan Selatan - Jakarta Barat Sumber: Penulis, 2019 


\section{Pendekatan Desain}

Desain menggunakan metode kontekstual dan analisis kawasan. Dilakukan dengan cara terjun langsung ke lapangan, menganalisa potensi dan masalah dari kawasan, memberikan masukan yang diharapkan dapat membantu menyelesaikan masalah di kawasan tersebut.

Site access untuk mengetahui jalur akses yang potensial untuk menuju tapak, baik menggunakan kendaraan pribadi ataupun kendaraan umum dan pejalan kaki. Output yang diberikan berupa penentuan entrance bangunan dalam tapak, jalur sirkulasi in-out pada bangunan di tapak. Site Green Network dengan penganalisaan ruang-ruang hijau yang ada di sekitar tapak, ruang hijau tersebut baik merupakan taman, lahan kosong, ataupun fasilitas umum yang ada. Dengan hasil dari penganalisaan tersebut terkait ke program yang akan diberikan ke dalam tapak. Korelasi antara bangunan dan lingkungan sekitar yang membuat bangunan menjadi lebih terbuka ke kawasan. Site Solid Void, dengan fokus terhadap solid void kawasan yang nantinya akan berpengaruh terhadap kenyamanan pengguna tapak di kawasan. Kecocokan program terhadap kawasannya sendiri dan tingkatan kenyamanan antara pengguna bangunan dengan area sekitarnya.

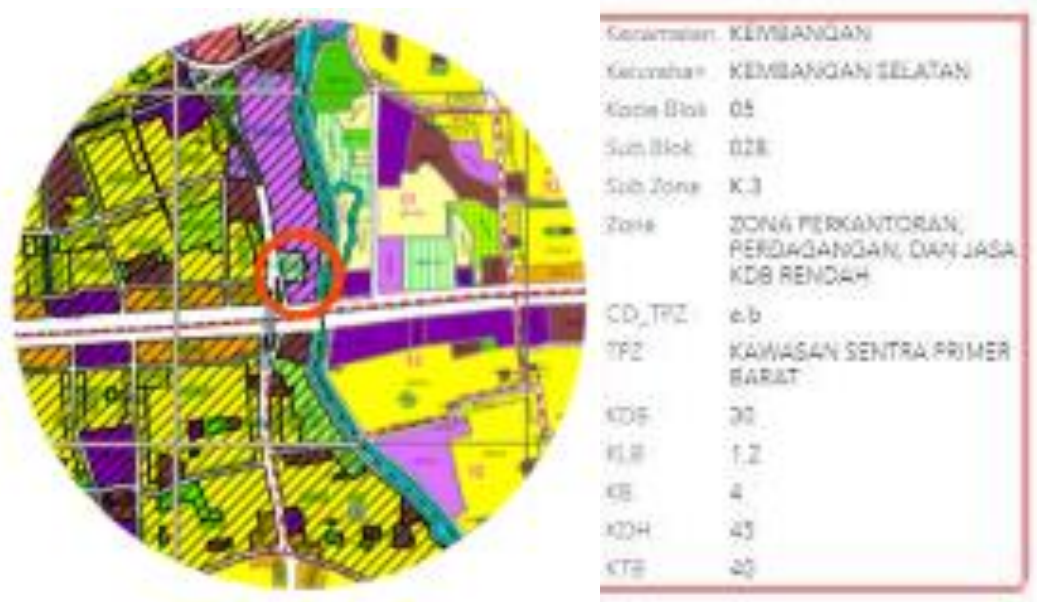

Gambar 8. Data Tapak

Sumber: RDTR Jakarta, 2019

Observasi terhadap bangunan di sekitar tapak dengan menganalisa bangunan- bangunan di sekitar tapak yang berpotensi terhubung dengan program olahraga yang berada di tapak. Program yang ada di dalam bangunan diharapkan juga dapat membantu menunjang kebutuhan kawasan dari segi kebutuhan akan kesehatan fisik dan mental. Dari hasil analisa yang diperoleh, tapak berlokasi di kecamatan Kembangan, Kelurahan Kembangan selatan dengan kode blok 05 dan sub blok 028. Merupakan zona perkantoran, perdagangan, dan jasa KDB rendah yang berarti dapat membangun fasilitas olahraga di dalam tapak. Dengan KDB sebesar 30\%, KLB: 1.2, KB: 4 lantai, KDH: 45\%, dan KTB: $40 \%$.

\section{DISKUSI DAN HASIL}

Kembangan Sport Center berlokasi di Kembangan Selatan, Jakarta Barat. Proyek terdiri dari program-program berupa; lobby + pocket park, foodcourt + news center, Esport study \& training area + arena hall, adult + child swimming pool, wall climbing area, billiard, muaythai, fitness + yoga area, spa + sauna dan public open space. Keseluruhan luas bangunan dengan luas $8900 \mathrm{~m}^{2}$ dimanfaatkan sebesar 60\% sebagai program utama dengan kapasitas penampungan maksimal 300 orang secara bersamaan serta pada area tribun e-sport arena dengan kapasitas $100-150$ orang. 

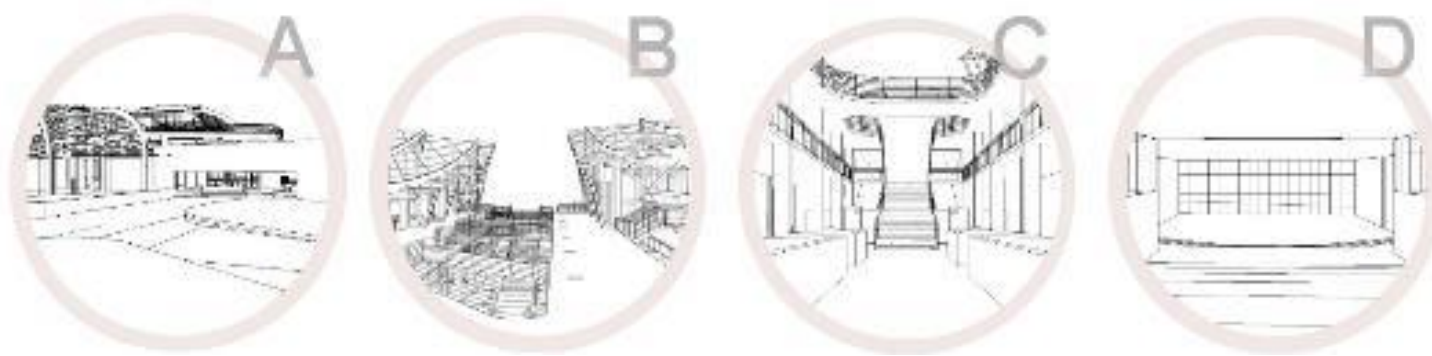

Gambar 9. Gambaran Ruang bangunan

Sumber: Penulis, 2019

Bentuk bangunan yang futuris mencerminkan karakter milenial yang kreatif. Korelasi program yang saling terhubung mempraktiskan akses dari pengguna. Pocket park di bangunan selain berfungsi sebagai taman rekreasi, juga dapat menghubungkan area lobby, e-sport arena, outdoor sport dan foodcourt sehingga sirkulasi tersusun secara praktis.

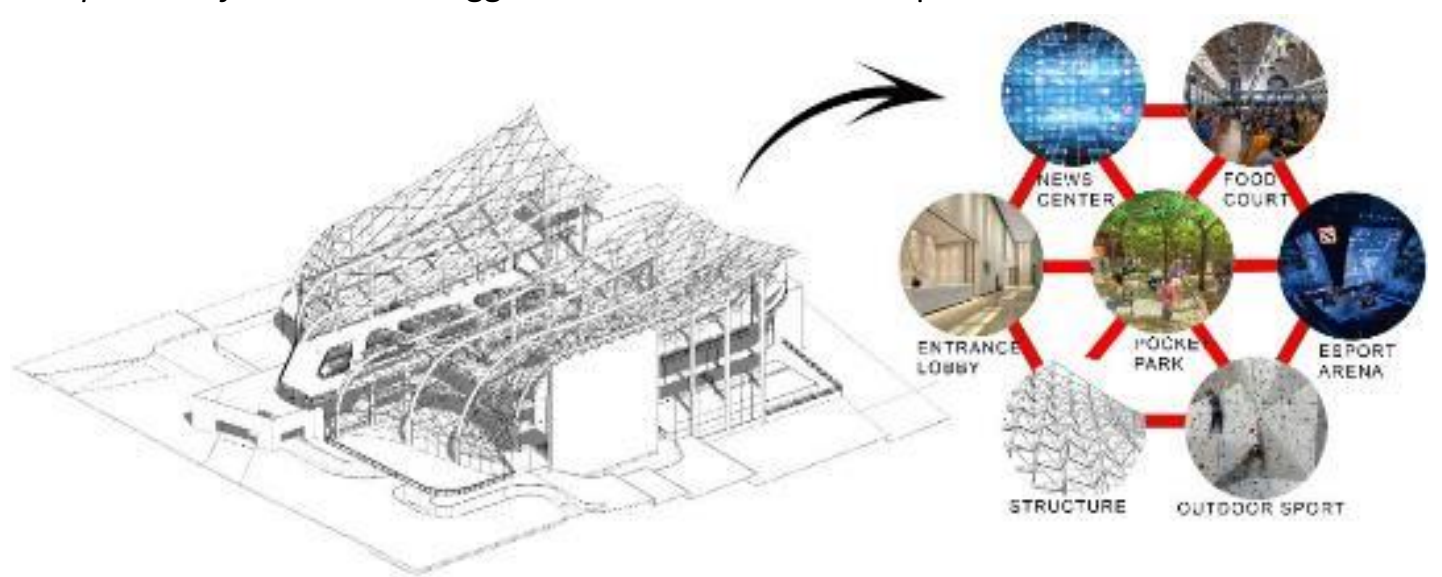

Gambar 10. Ilustrasi Program Dalam Bangunan Sumber: Penulis, 2019

Perencanaan desain mencakup struktur yang memenuhi kriteria gedung olahraga, outdoor sport dengan kreatifitas dari karakter milenial, news center sebagai informasi olahraga terbaru, pocket park penghubung program utama dengan mengusung sistem praktis.

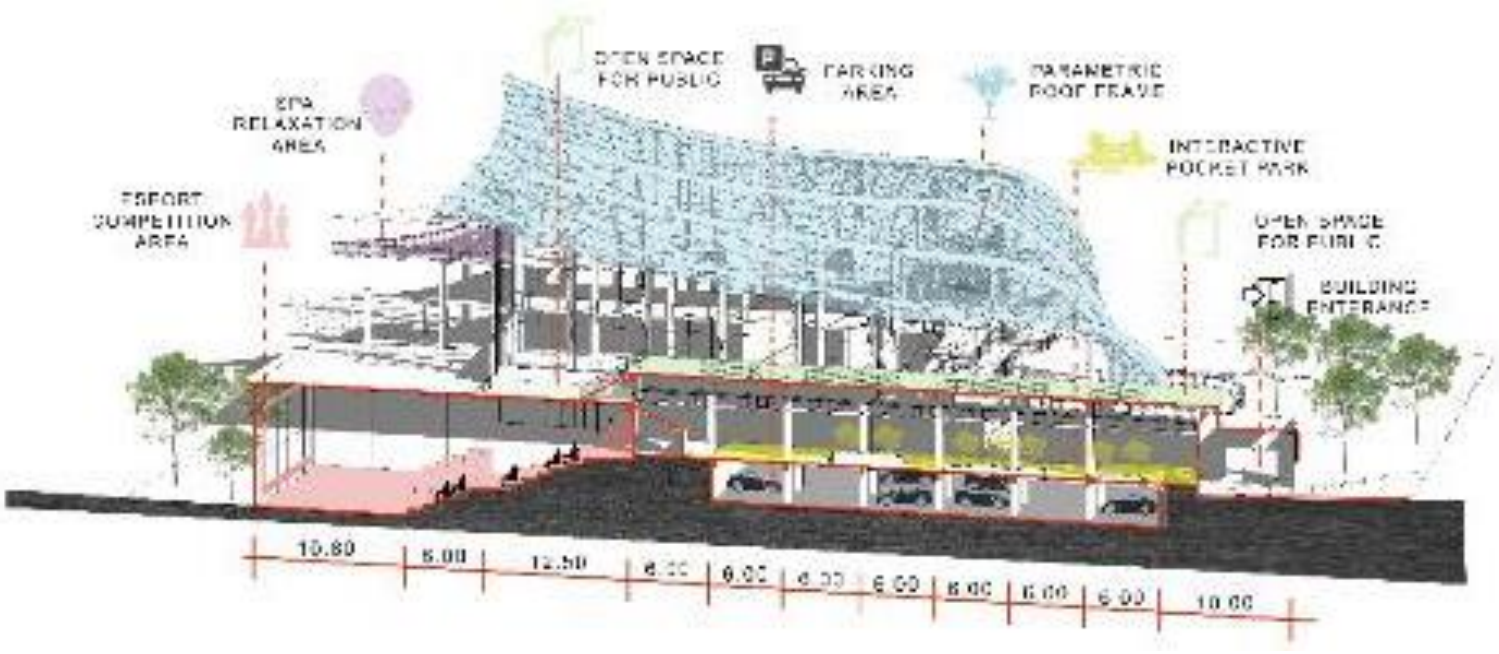

Gambar 11. Peletakan Zoning Berdasarkan Potongan Bangunan Sumber: Penulis, 2019 
Fokus desain ruangan yaitu, mencoba mengambil dari ide kreatif milenial dimana desain menghadirkan suasana baru bagi pengunjung sehingga dapat membantu menahan karakter mudah bosan dari milenial. Selain itu terdapat program pendukung yang membantu menunjuang efektifitas dari penggunaan ruang.

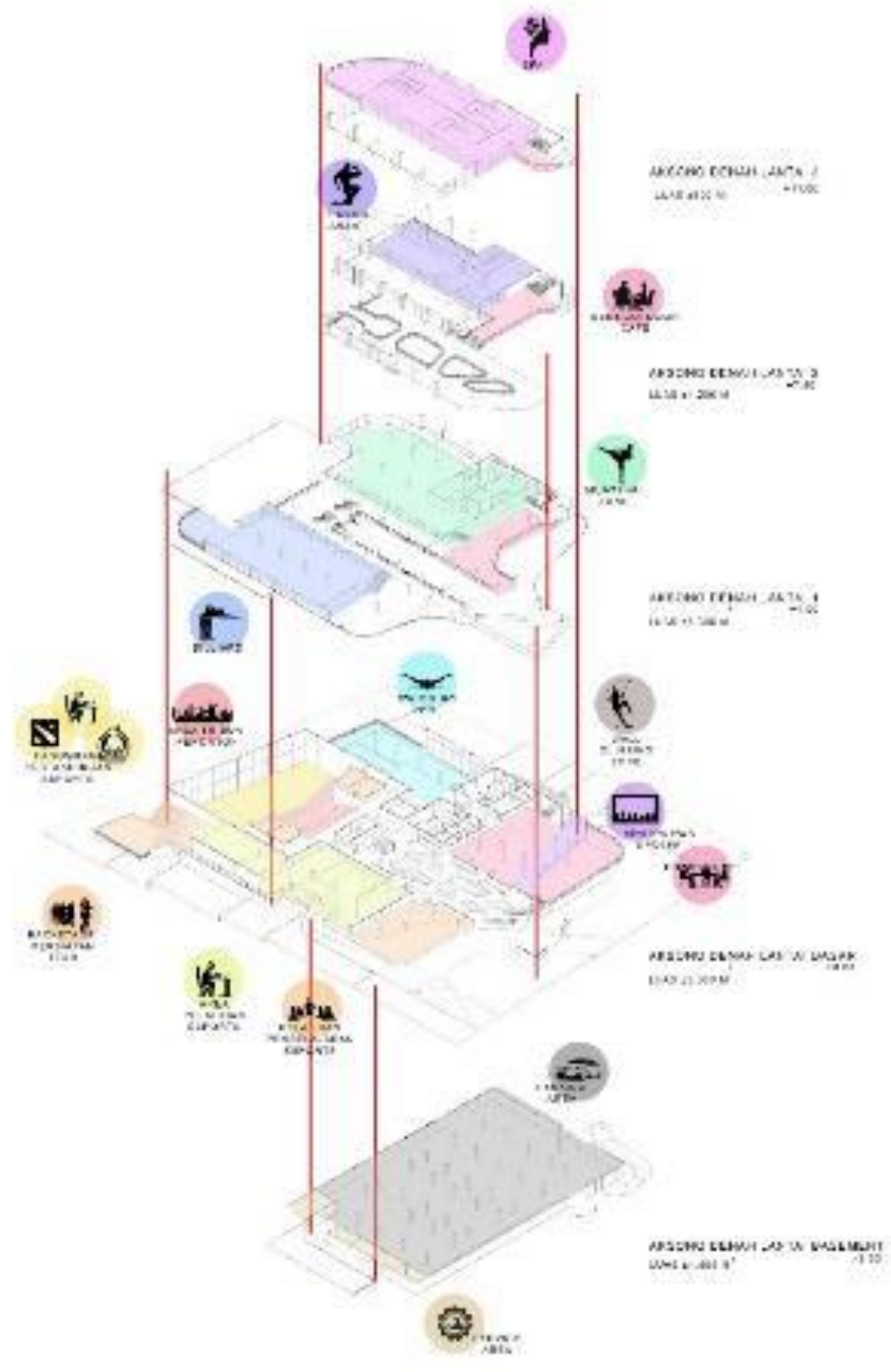

Gambar 12. Aksonometri Program

Sumber: Penulis, 2019

Peletakan zoning pada bangunan disesuaikan dengan kebutuhan pengguna agar efektif mengakses bangunan. Selain itu penggunaan dinding didominasi oleh kaca dengan tujuan sebagai vocal point di suatu kawasan dan meminimalisir terjadinya pembayangan di dalam ruang. Aktivitas olahraga tidak akan terasa nyaman dan akan susah mencapai konsentrasi jika terdapat pembayangan di area aktivitas.

Proyek Kembangan Sport Center dibagi menjadi beberapa zona berdasarkan komposisi dan luasan program yang ditentukan. Pada bagian lantai dasar diberikan ruangan yang bersifat publik dimana seluruh pengunjung dapat langsung mengakes ke ruangan tanpa perlu dilakukan pengawasan dan registrasi area tersebut mencakup pocket park, foodcourt+news center, $e$ sport area, dan kolam renang. Lantai 1 mencakup program olahraga yang bersifat umum namun juga memerlukan pengawasan serta bersifat indoor. Lantai 2 dan 3 berisi program pendukukung berupa area fitness + yoga, dan area sauna + spa (Gambar 12 dan 13). 

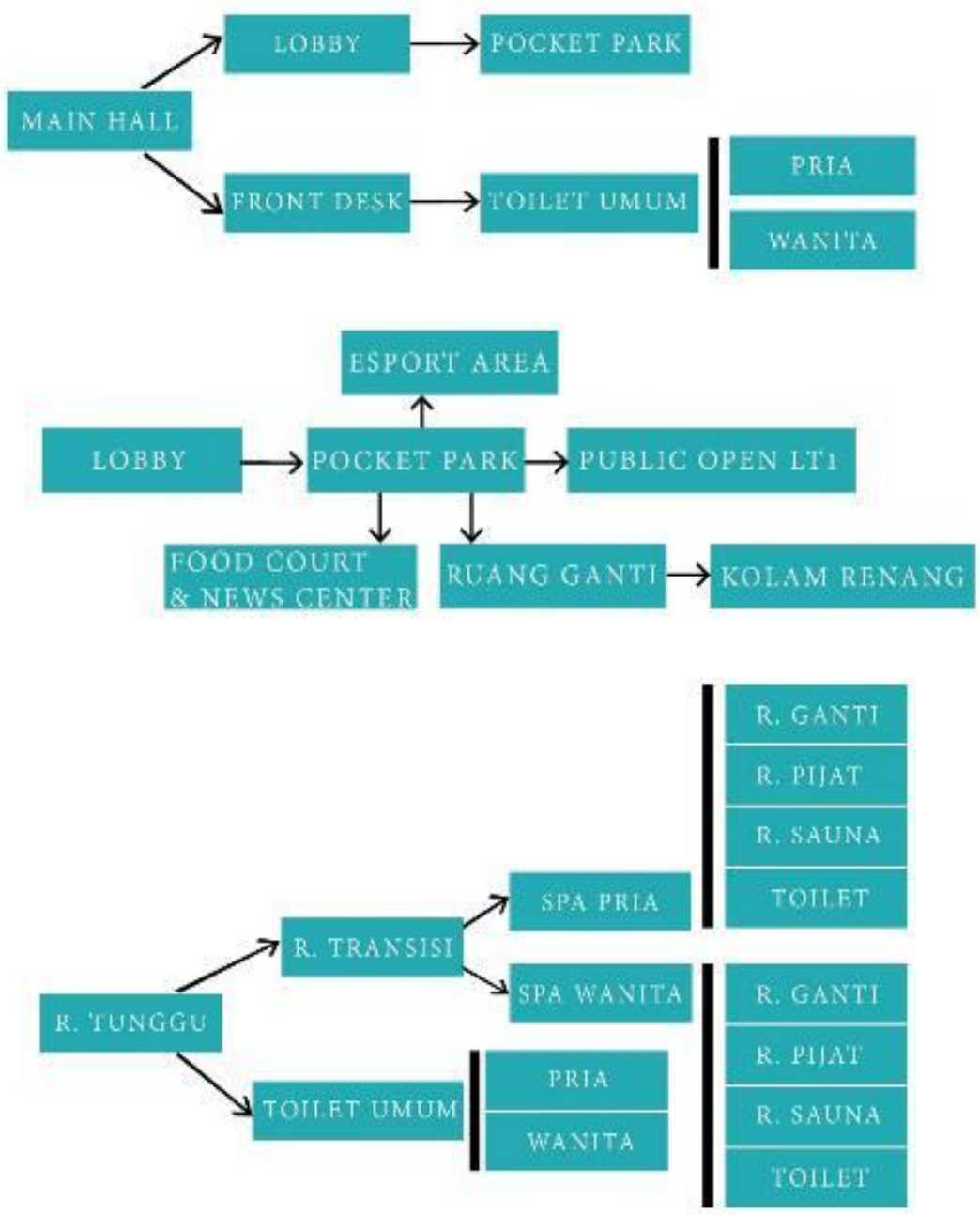

Gambar 13. Organisasi Kembangan Sport Center Sumber: Penulis, 2019

Penerapan konsep individual creative didasari dari pencarian terhadap kebutuhan millenial akan fasilitas olahraga hiburan sebagai penghilang stress. Penggabungan setiap program olahraga hiburan di dalam satu wadah menjadi sebuah terobosan baru dalam memecahkan masalah pada milenial. Karakteristik yang dipenetrasi ke dalam bangunan diperoleh dari sifat efektif pada milenial. Peletakan program yang saling berhubungan sehingga mempermudah akses sirkulasi di bangunan.

\section{KESIMPULAN DAN SARAN}

Kembangan Sport Center merupakan tempat untuk berolahraga yang bertujuan untuk menghilangkan stress dan merelaksasikan diri milenial secara jasmani. Hal tersebut didukung dengan pemberian fasilitas yang diperoleh dari hasil analisis karakter yang diterapkan ke dalam program. Proyek ini hadir sebagai respon dari kondisi keaadan lingkungan sekitar tapak agar menjadi kawasan yang lebih baik di masa depan. 


\section{REFERENSI}

Anonim. (2017). 10 Macam-macam Cabang Olahragadi Indonesia. Diperoleh dari https://gurupenjaskes.com/macam-macam-cabang-olahraga-di-indonesia

Catanese, A. J.( 1979). Intoduction to Urban Planning.

Centre For Strategic and International Studies.( 2017). Ada Apa Dengan Milenial. Diperoleh darihttps://www.csis.or.id/uploaded_file/event/ada_apa_dengan_milenial__papara n_survei_nasional_csis_mengenai_orientasi_ekonomi_sosial_dan_politik_generasi_ milenial_indonesia_notulen.pdf

Ester. (2016). Mengenal Generasi Millenial. Diperoleh dari https://www.kominfo.go.id/content/detail/8566/mengenal-generasimillennial/0/sorotan_media

Kota Administrasi Jakarta Barat. Rencana Strategis. Rencana Pengembangan Kawasan Pemukiman. Rencana Pengembangan Sistem Prasarana Transportasi.

Neufret, E. ( 1996). Data Arsitek Jilid 1. Jakarta: Penerbit Erlangga

Neufret, E. (2002). Data Arsitek Jilid 2. Jakarta: Penerbit Erlangga

Pradewo, B. (2019). Infrastruktur dan Ekonomi Jakarta Barat Semakin Berkembang. Diperoleh dari https://www.jawapos.com/jpg-today/22/06/2018/2019-infrastruktur-danekonomi-jakarta-barat-semakin-berkembang/

Utama, I. G. B. R. (2011). Health and Wellness Tourism Jenis dan Potensi Pengembangannya di Bali. Diperoleh dari https://tourismbali.wordpress.com/2011/03/08/health-andwellness-tourism-jenis-dan-potensi-pengembangannya-di-bali/

Wanto, R. F. (2015). Sportaiment, Olahraga Kian Melebur Dengan Hiburan. Diperoleh dari Investor Daily Indonesia.

Zipjet. (2017). The 2017 Global Least \& Most Stressful Cities Ranking. 